\title{
Research Paper \\ Designing a Family- Centered Behavioral Management Program (FBMP) and Assessing its Effectiveness in Reducing Symptoms of Attention Deficit and Hyperactivity Disorder
}

\author{
Aliakbar Torabi ${ }^{1}$, Gholamali Afrooz ${ }^{* 2}$, Fariba Hsani ${ }^{3}$, Fateme Golshani ${ }^{3}$
}

1. Ph.D. Student of Psychology, Central Tehran Branch, Islamic Azad University, Tehran, Iran

2. Professor, Department of Psychology, Faculty of Psychology and Educational Sciences, University of Tehran, Iran

3. Assistant Professor, Department of Psychology, Central Tehran Branch, Islamic Azad University, Tehran, Iran

Citation: Torabi A, Afrooz G, Hsani F, Golshani F. Designing a family- centered behavioral management program (fbmp) and assessing its effectiveness in reducing symptoms of attention deficit and hyperactivity disorder. Quarterly Journal of Child Mental Health. 2020; 7(1): 257269.

\section{$\underline{\text { http://dx.doi.org/10.29252/jcmh.7.1.22 }}$}

\section{A R T I C L E I N F O}

Keywords:

Family-centered behavioral management program (FBMP), ADHD, primary school children

Received: 18 Sep 2019 Accepted: 14 Mar 2020 Available: 20 Jun 2020

\section{A B S T R A C T}

Background and Purpose: Attention Deficit and Hyperactivity Disorder (ADHD) is one the most prevalent disorders in childhood and adolescence. Children with ADHD have usually different problems in controlling their behaviors. Their families are confronted with many doubts and conflicts in managing the behaviors of these children. This study aimed to design a family-centered behavioral management program (FBMP) and assess its effectiveness in reducing the symptoms of ADHD in the primary school students.

Method: This study was an applied research with quasi-experimental pretest-posttest control group design and follow-up stage. The statistical population included the parents of all primary school children with ADHD in Tehran city in the academic year 2018-2019. 64 parents out of this population were selected by convenience sampling and then randomly assigned to either the experimental or control group. The experimental group received ten 90-min sessions of FBMP, while the control group was put on a waiting list to receive it. Data were collected by Conner's Teacher and Parent Rating Scale (1999). Repeated Measures ANOVA was used to analyze the data.

Results: Data analysis by repeated measures ANOVA revealed that FBMP was significantly effective in reducing the symptoms of ADHD in the primary school children. Findings showed that there was a significant difference between the groups in the posttest (55.13) and follow-up stage (46.75) $(\mathrm{P} \leq 0.05)$. Therefore, results showed that the program was significantly effective in reducing the symptoms of ADHD and this efficacy was stable during the 2-month follow-up period.

Conclusion: Based on the results of this study, it can be concluded that FBMP makes a better transaction between the children with ADHD and their parents and shapes a better understanding between them, which ultimately leads to improvement of child's behavior.

\footnotetext{
* Corresponding author: Gholamali Afrooz Professor, Department of Psychology, Faculty of Psychology and Educational Sciences, University of Tehran, Iran.

E-mail addresses: Afrooz@ut.ac.ir
} 


\title{
طراحى برنامه مديريت رفتارى خانوادهمحور و اثربخشى آن بر كاهش نشانه هاى اختلال نارسايى توجه - فزون كنشى
}

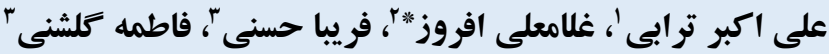

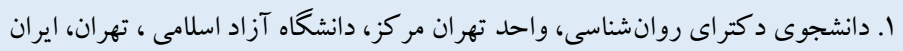

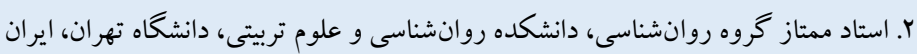

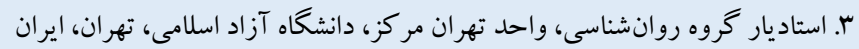

زمينه و هدف: اختلال نارسايى توجه و فزون كنشى يكى از رايجترين اختلالات دوران كودمى و ونوجوانى است كه كود كان مبتلا به آن،

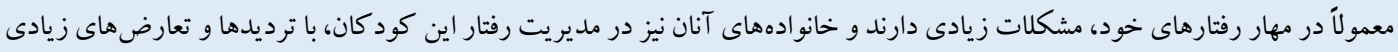

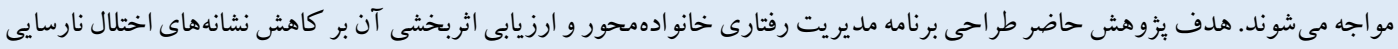
توجه و فزون كنشى كود كان دبستانى، است.

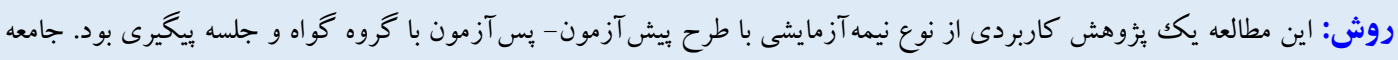

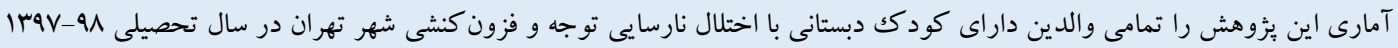

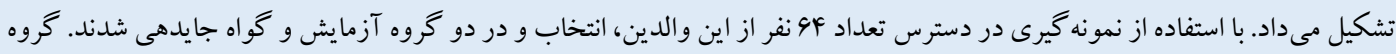

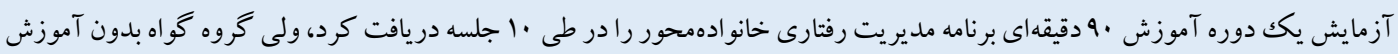

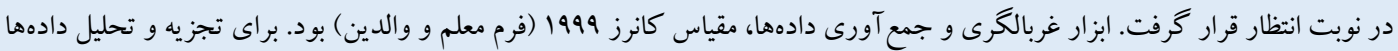
از مدل آمارى تحليل واريانس با تكرار سنجش (درون بين آزمودنى) استفاده شد.

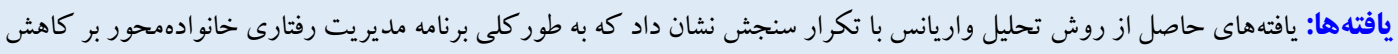

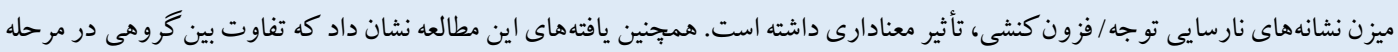

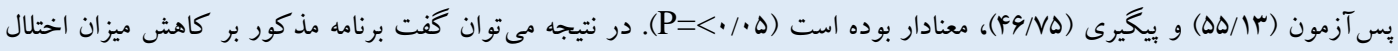

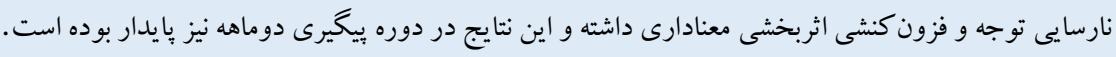

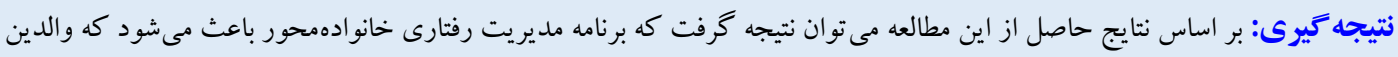
دريافت شده: 9N/. 9/TV

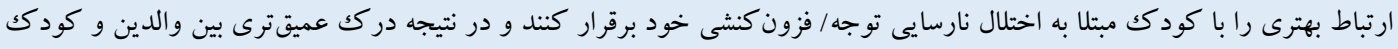

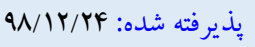

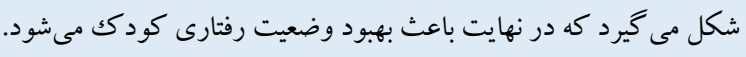

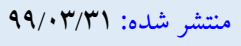


بررسـى تأثير آموزش والدگرى مثبت مبتنى بر روى آورد سـاندرز بر افزايش شـادزيسـتى و كـاهش تعارض والد- فرزندى بـ دانش آموزان

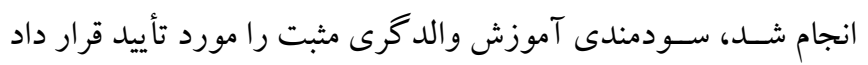

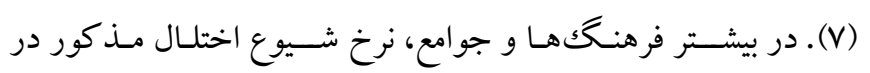

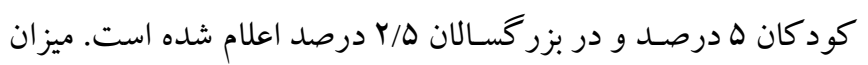

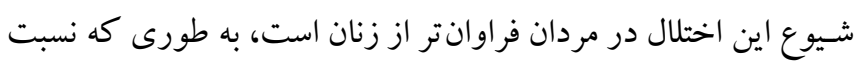

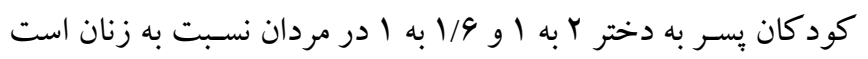

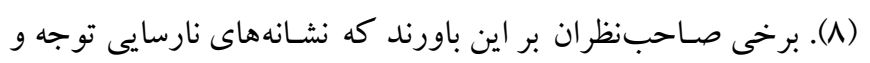

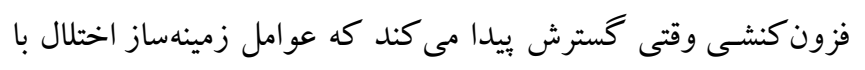

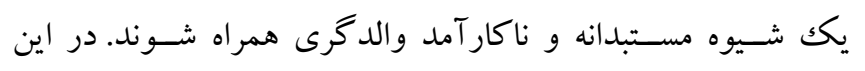

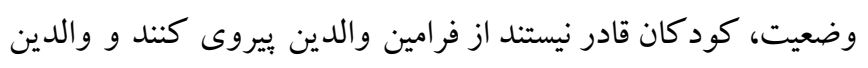

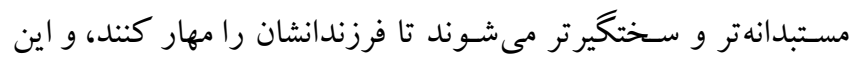

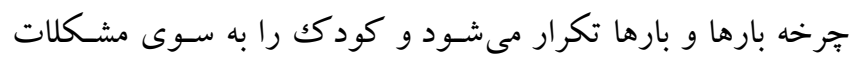

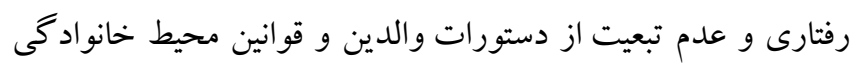

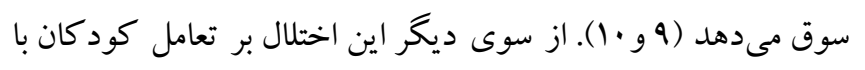
والدينشـان و نيز شـــوه پِاســخدهى والدين به اين كود كان تأثير مى گذارد، زيرا اين كودكان بسـيار برحرف، منفى گرا، و بـى بـاعتنا

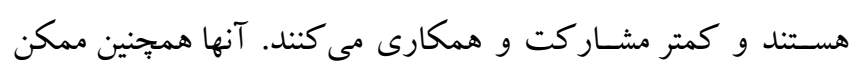

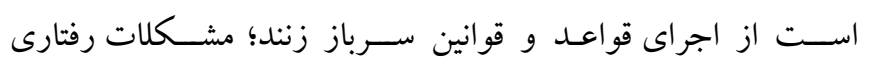

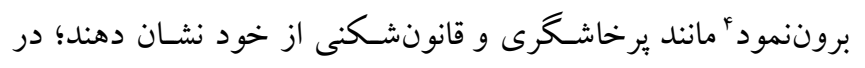

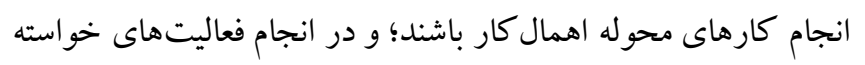

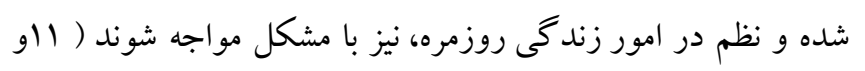

برنامهاى خانوادهمحور آموزش والدينه باعث تغيير نكرش اعضــاء

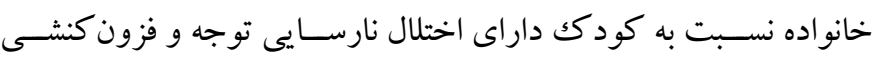
مىشود؛ بنابر اين يذيرش و نكرش مثبت خانو ادهها نسبت به اين كود كان،

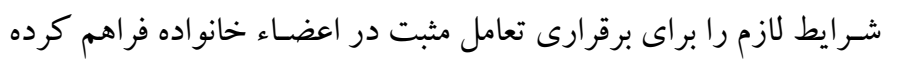

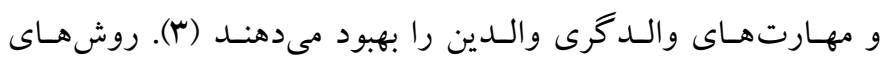

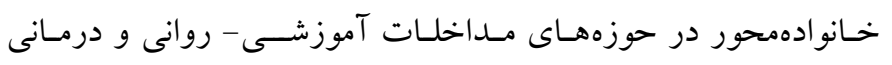

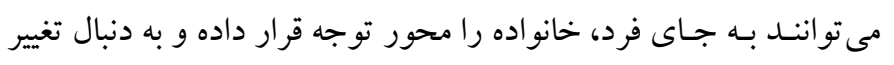

4. Outward behaviors

5. Family-centered parent training programs

\section{مقلهمه}

كود كـان بـا اختلـال نـارســيى توجه و فزون كنشــى'، معمولا در مهار

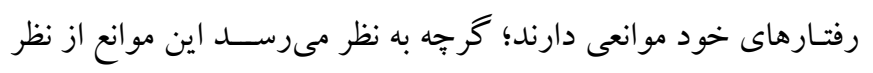

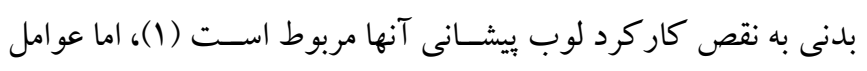

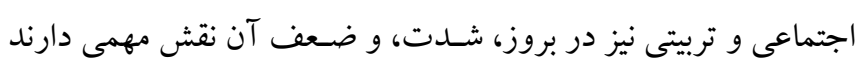

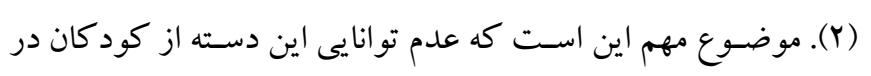

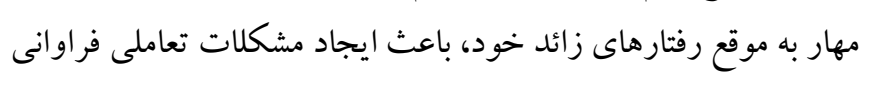

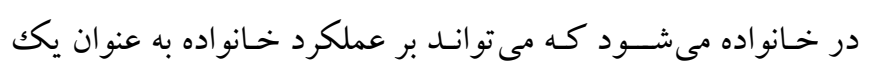

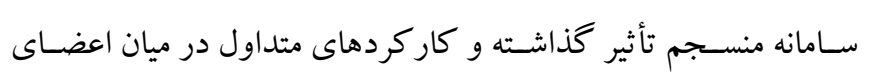

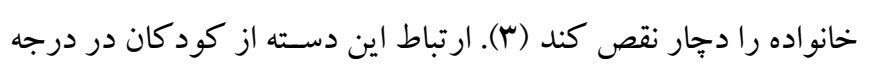

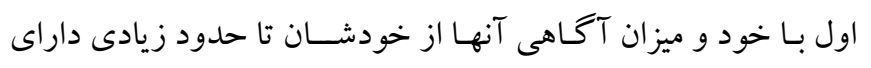

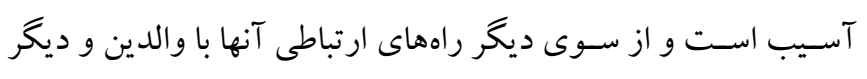

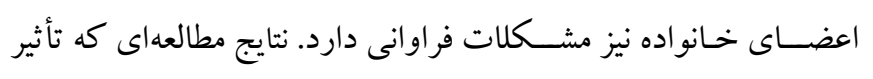

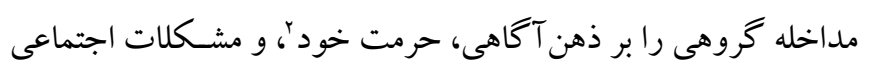

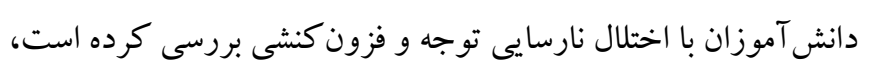

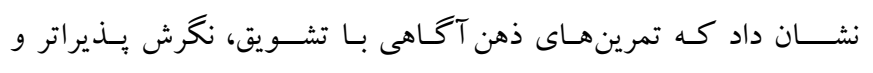

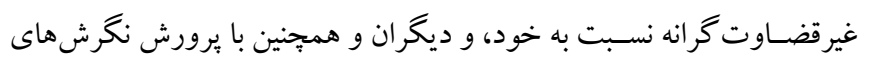

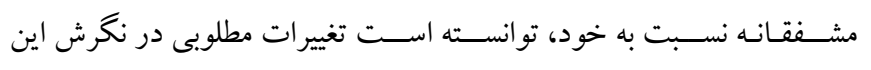
دانش آموزان نسـبت به خود و سـبك ارتباطى آنها با خود بديد آورد (F).

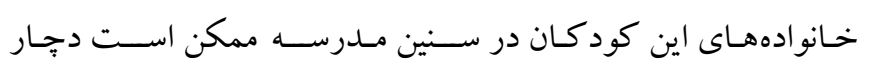

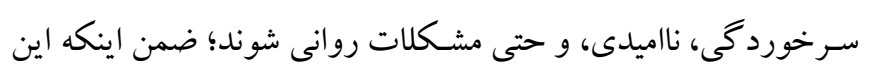

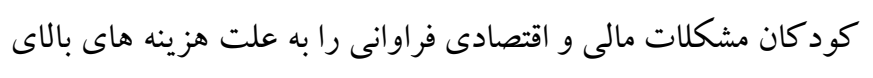
درمانى، به خانو اده خود تحميل مى كنند (ه).

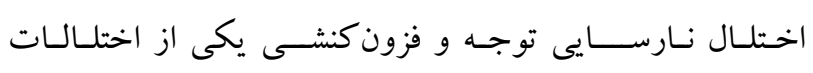

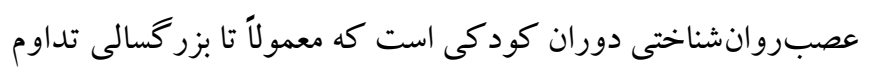

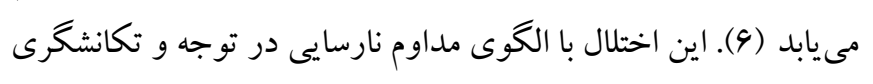
مشخص مىشود كه در سنين كودكى بروز ييدا مى كند. در اين اختلال

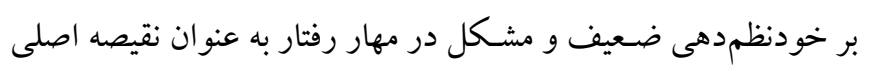

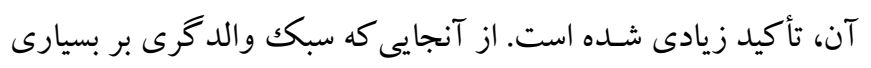

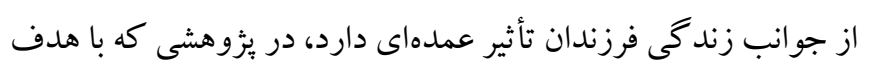

1. Attention Deficit and Hyperactivity Disorder(ADHD)

2. Mindfulness and self-respect

3. Happiness and reduction of parent-child conflict 
والد و والد-كودكى) را ترميم و اصلاح كند و اثربخشى مناسبى بر كاهش

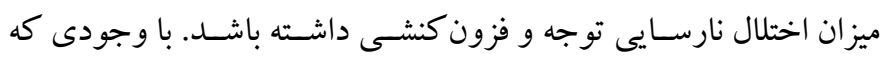

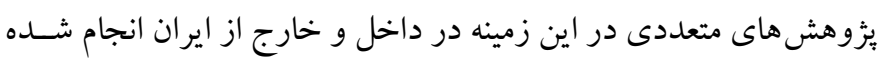

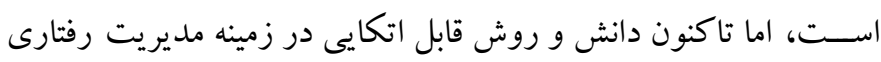

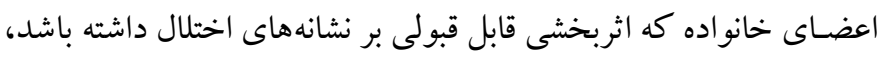

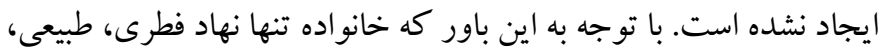

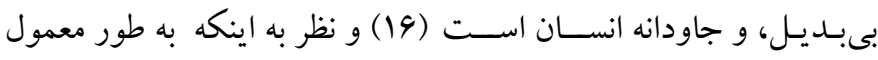

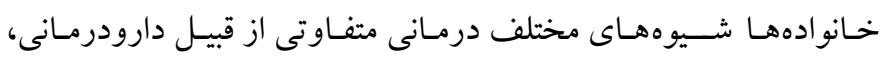

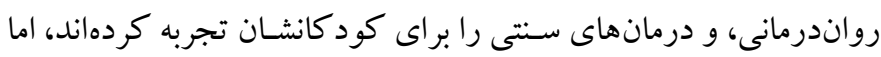

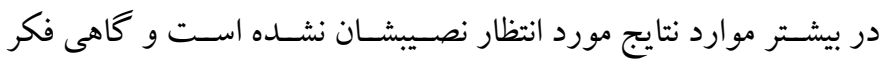
مى كنند زندگى آنها با آرامش، فاصسله زيادى دارد و احسـاس رضـايت

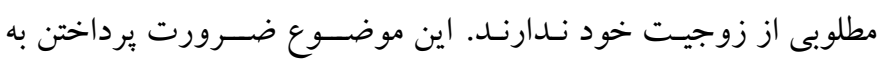

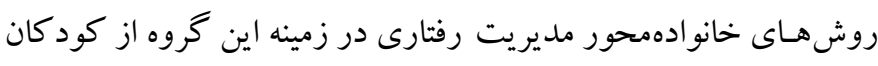

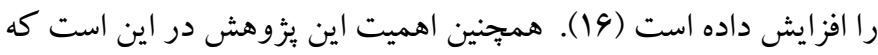

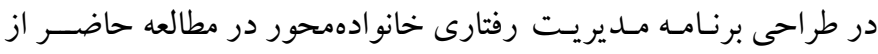
برنامه آموزش رفتارى - ارتباطى بار كلى (r) كه اثربخشسى آن در ايران

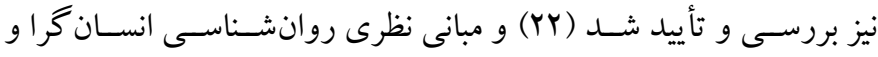

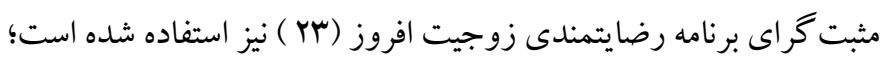

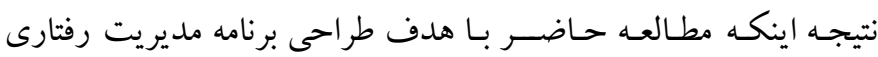

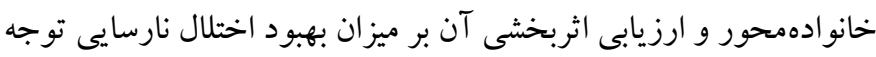
و فزون كنشى كود كان دبستانى انجام شد.

روش

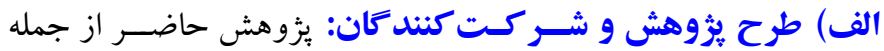

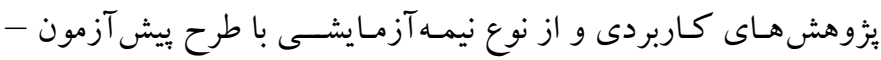

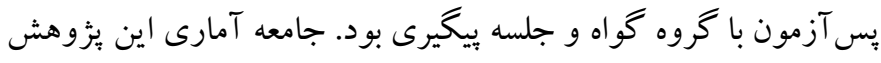

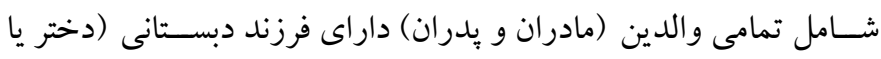
يسـر) مبتلا به اختلال نارسـايى توجه و فزون كنشسى شـهر تهران در ســال تحصيلى

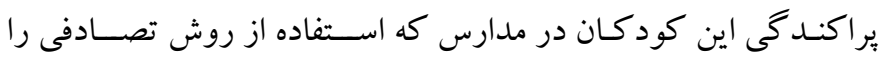

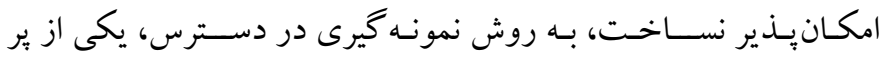
جمعيت ترين مدارس ابتدايى شهر تهران (هر دو نوبت بسرانه و دختر انه)
الكوهاى ارتباطى اعضـا با يكديخر باشـــد (rا). يُزوهشى كه به منظور

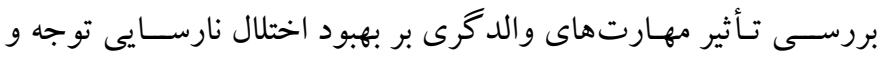

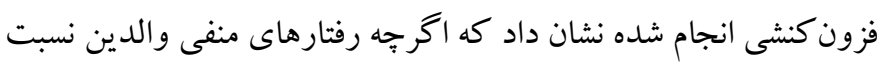

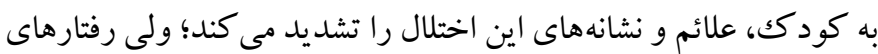

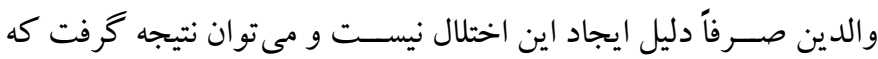

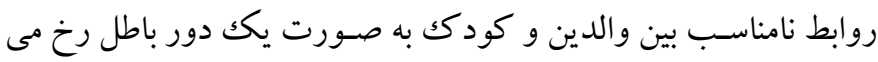
دهد (F) (I). بررسى ها نشان دادهاند كه تنظيم رفتار والدين به ويزه مادران

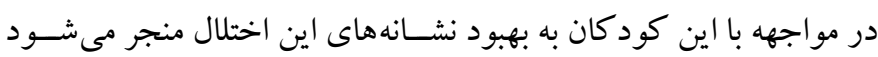

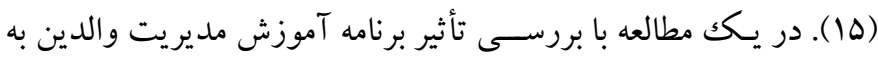
ويزه مادران باردار، نشـان داد كه مداخله آموزشى با كاهش علائم اختلال

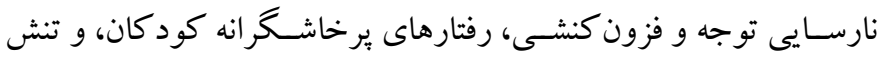

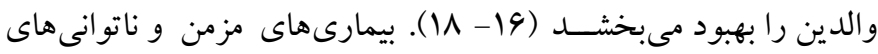

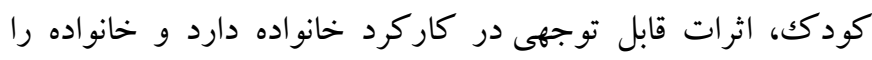

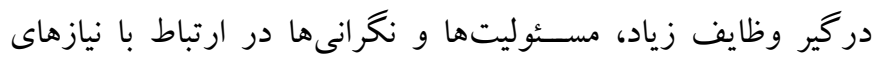

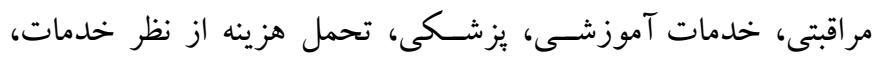

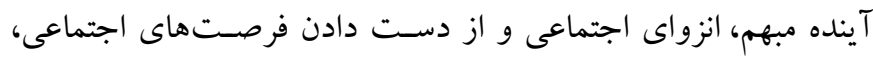
غيبت زياد از كار، مشـكلات مالى، جسـمى، و و عاطفى مى كند (19).

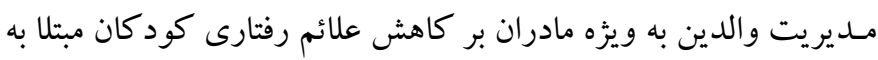

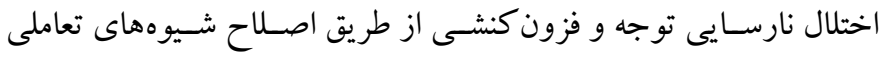

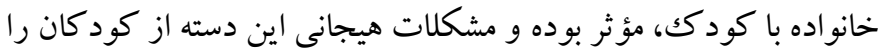
بهبود مىبخشد (·r). هر قدر نظام خانواده از استحكام بيشترى برخوردار باشـد و روابط ميان اعضاى آن عاطفى تر و عقلانى تر باشد، فرزندان نيز از

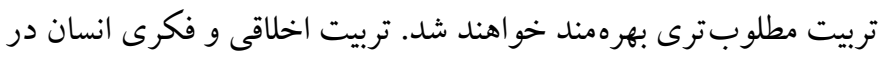

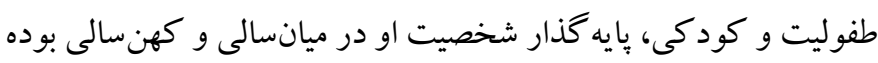
و تعـادل در تربيت مســتلزم همزمانى تحول جســمانى، عاطفى، و ذهنى

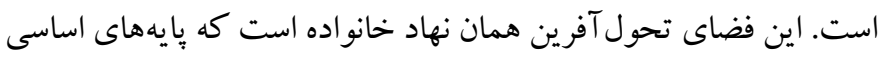

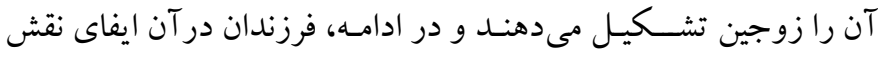

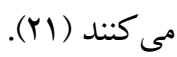
از آنجا كه هدف اصسلى در بثزوهش حاضـر طر احى برنامه مديريت

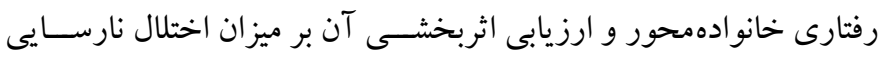

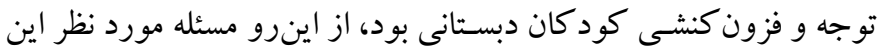

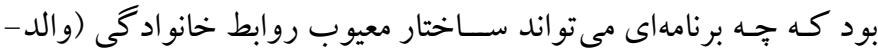


جـهـ امتيـاز فرد بـالـاتر رود، ميزان اختلـال كودكك بيشــتر خواهـد بود و

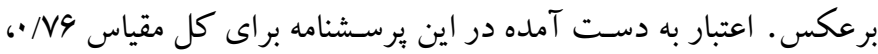

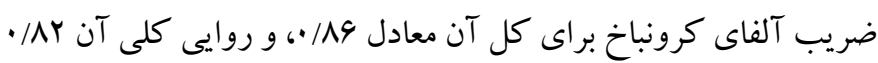

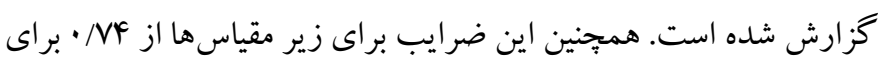

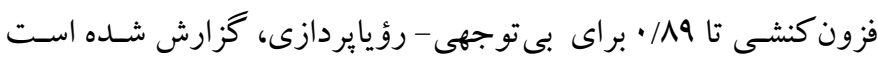

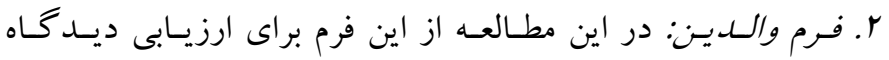

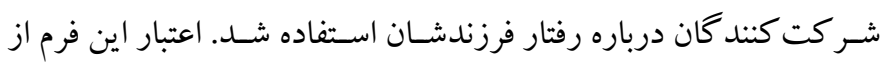

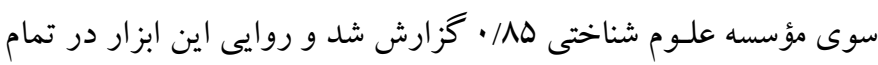

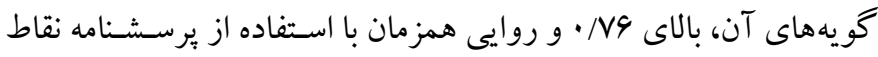
قوت و دشـوارى' ، ·r=/Vو دور زمينه تعيين ارزش تشـخيصى والدين

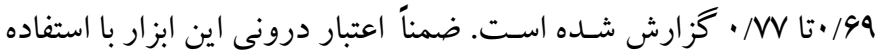

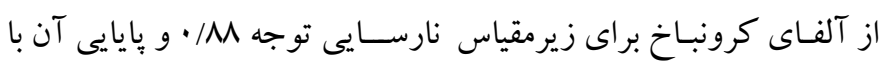

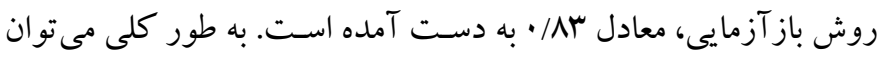

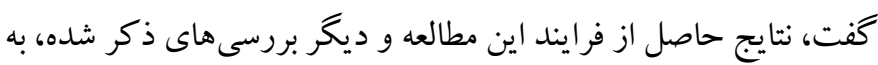
روشنى نشانگر روايى و اعتبار مطلوب نسخه فارسى بر سشنامه كانرز (فرم

$$
\text { والدين) است (r) (r). }
$$

ج) معرفى برنـامه مداخلهاى : برنامه مديريت رفتارى خانو ادهمحور با

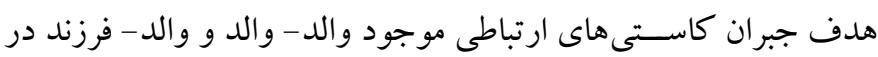

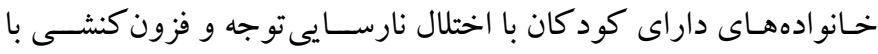

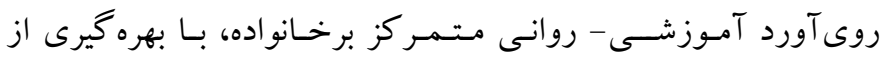

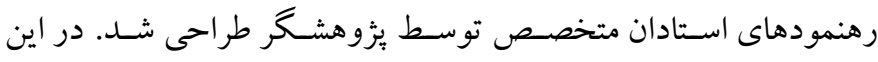

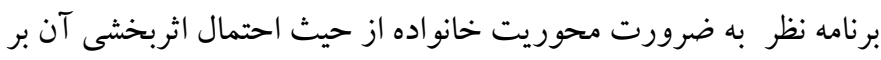

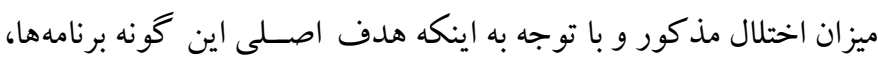

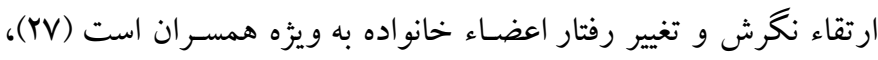

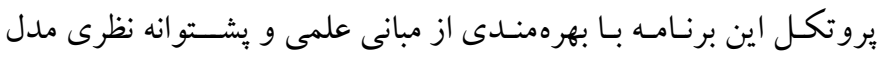

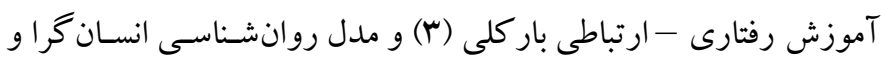

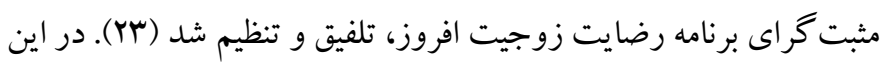

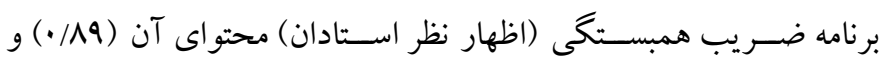

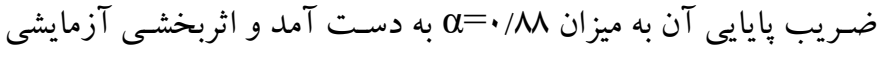

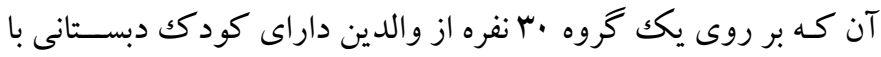

انتخاب شــــ ابتدا اســـى • rا دانش آموز كه بر اســاس فرم معلم كانرز

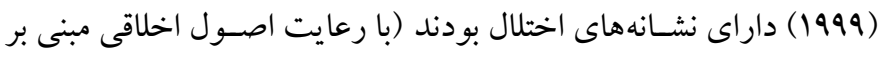

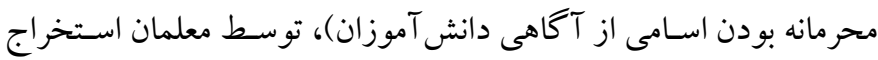

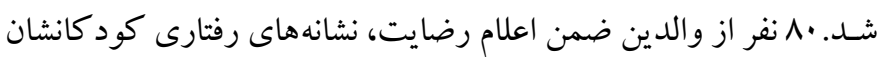

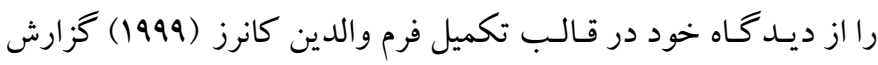

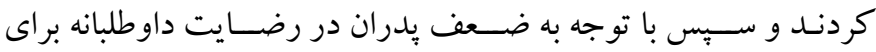

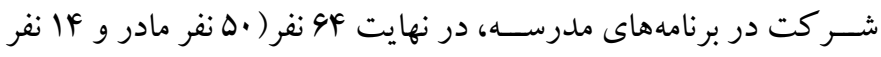

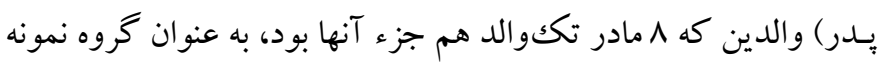

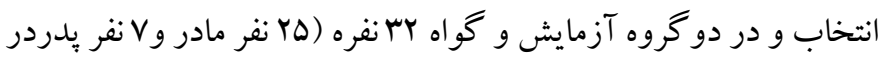

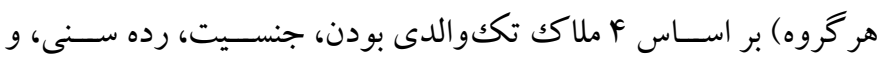
ســـ تحصـيلات، مطابق اطلاعات مندرج در بخش اول فرمهاى تكميل

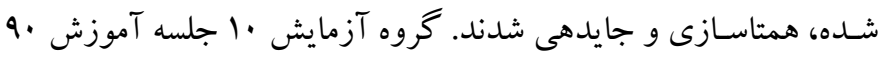

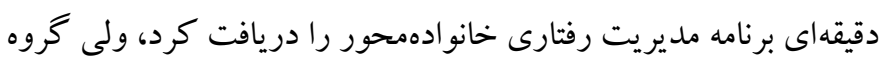

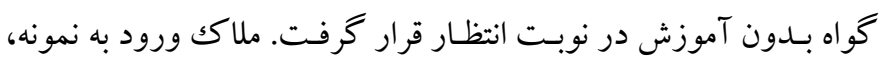

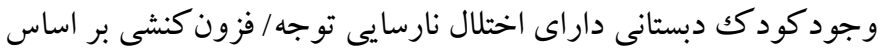

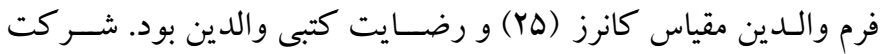

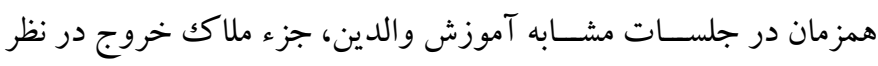
كرفته شده بود. ب) ابزار: در يزوهش حاضر با توجه به هدف اصلى يثزوهش حاضر مبنى

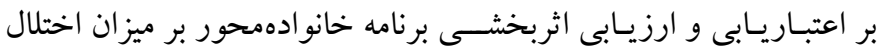

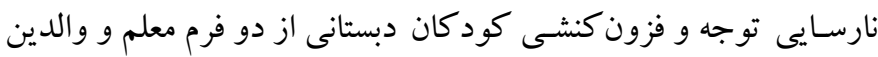
مقياس درجهبندى كانرز (1999) به عنوان ابزار يُزوهش استفاده شد:

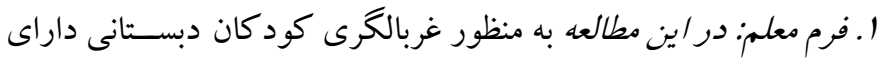
علائم و نشانه هاى اختلال نارسـايى توجه و فزون كنشى در مدرسه، از فرم

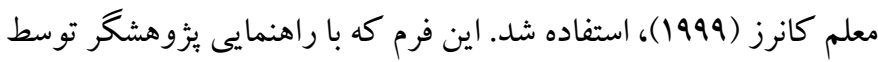

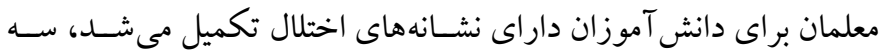

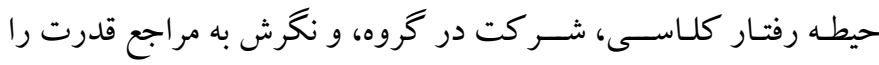

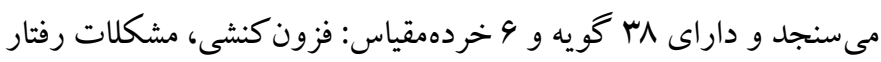

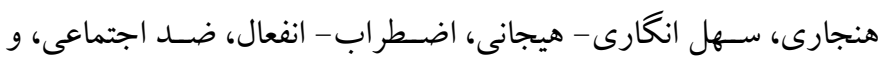

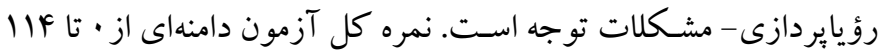
دارد. اخر نمره كودكك بالاتر از له به دست آيد، بيانگر اختلال بوده و هر 
آزمودنى ها تجويز مىشــد و براى برخى تكاليف از آنها خواسـته مىشـــ

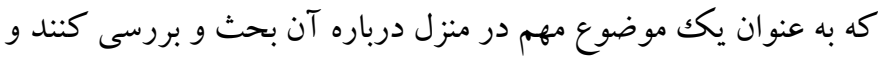

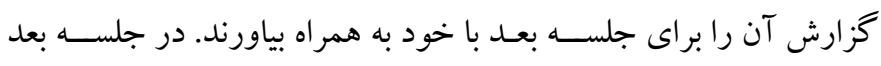

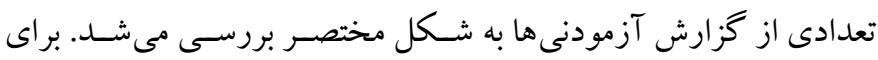

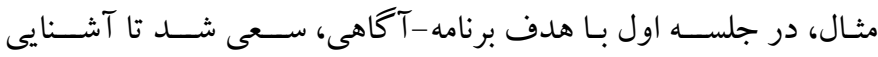

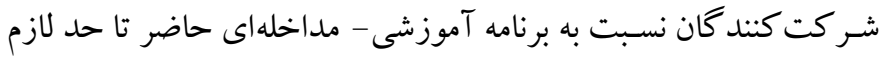

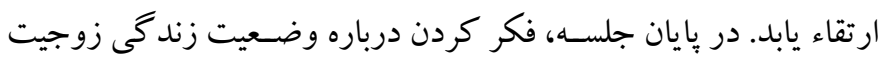

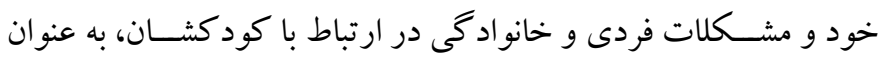

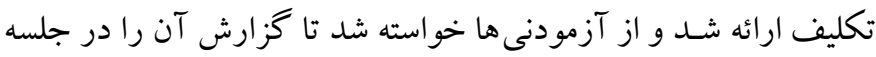
بعد همر اه داشــه باشــند. للازم به ذكر اسـت كه اين برنامه يس از مشخص

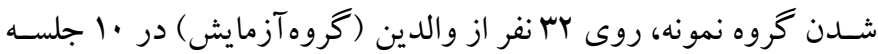

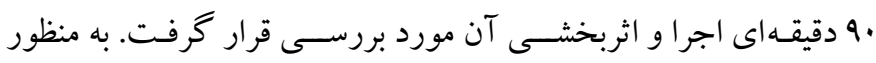

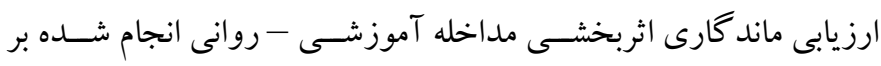

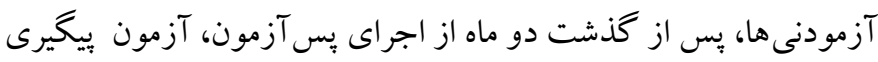

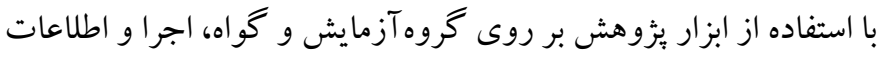

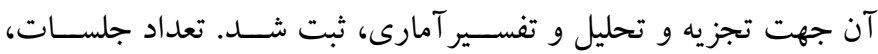

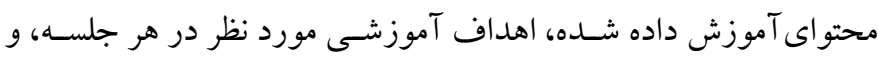
تكاليف ارائه شده در جدول اكزارش داده شده اهد است.
اختلال نارسـايى توجه و فرون كنشـى (مراجعه كننده به مراكز مشــاوره

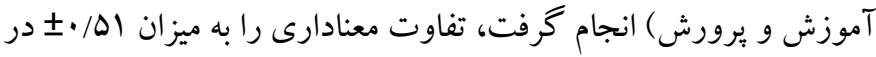

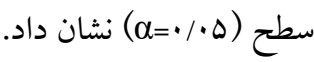

قابل ذكر اسـت كه اثربخشى برنامه بار كلى، طى مطالعهاى در سـال

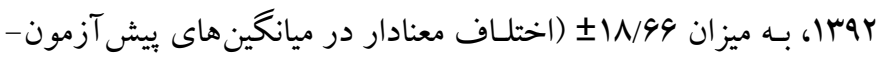

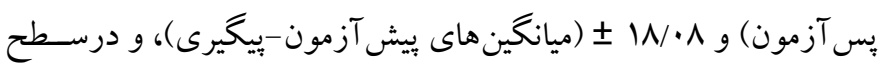

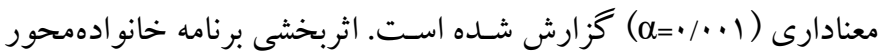

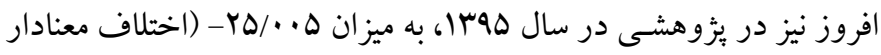

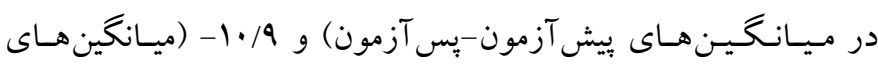

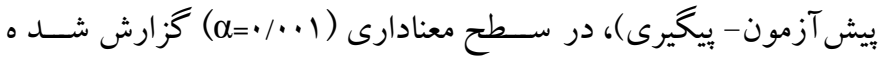

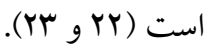
برنـامـه مـديريت رفتارى خانوادهمحور كه اعتبار و اثربخشــى آن بر اسـاس فرايند ذكر شده در يكك مطالعه مقدماتى تأييد شد متشكل از يكك يروتكل آموزشسى ده جلسـهاى بود كه براى هريك از جلسـات، عنوان

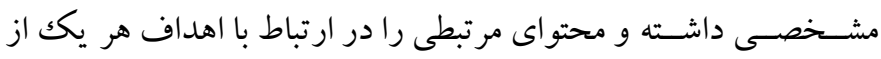
جلسـات، مورد توجه قرار مى داد. در هايان هر جلســـهـ به منظور بالا بردن

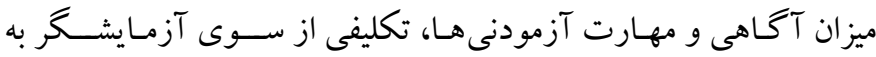

جدول ا: برنامه مديريت رفتارى خانوادهمحور

\begin{tabular}{|c|c|c|c|}
\hline تكاليف & محتوا & 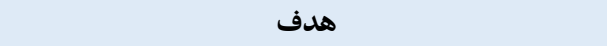 & 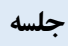 \\
\hline 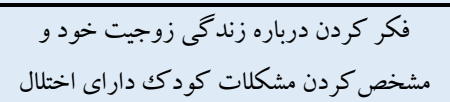 & 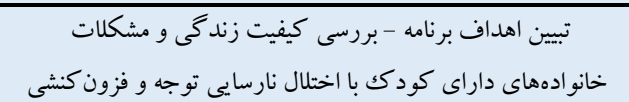 & 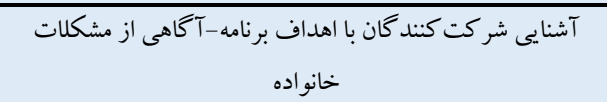 & 1 \\
\hline 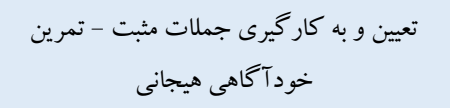 & صداقت، باور به هدف آرامش در سايه ازدواج، تعهدات اخلاقى، & احياى اهداف و آرمانهاى ازدواج - ارتقاء صميميت & r \\
\hline 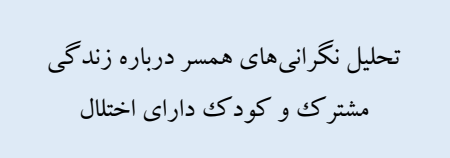 & 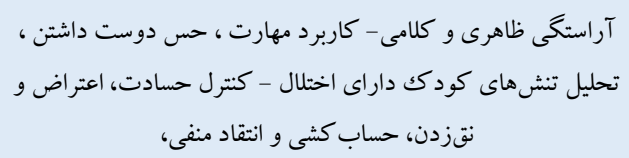 & اهميت احساس همسر درباره كودك،، ارتقاء تعهد مشتر كك نسبت & $r$ \\
\hline 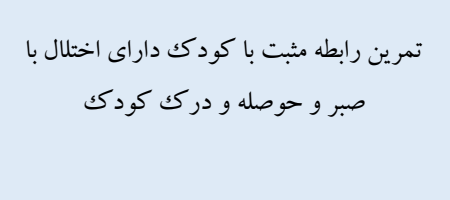 & 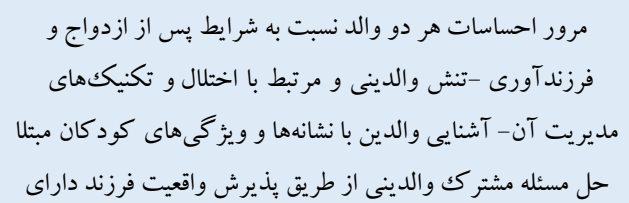 & 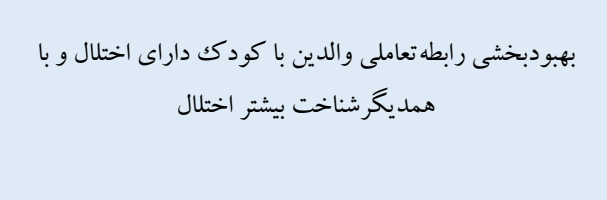 & f \\
\hline منطقين هماهنكى تربيتى (به كار كيرى سبكك & 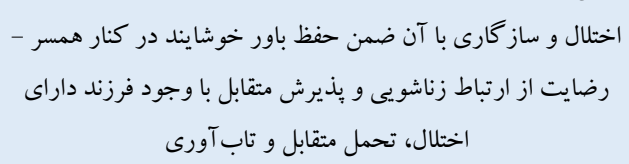 & 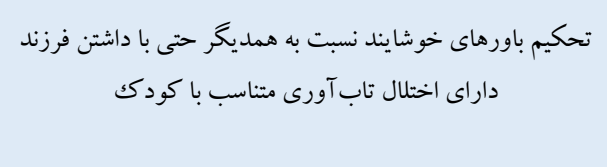 & $\Delta$ \\
\hline استفاده از روش ايفاى نقش در كلاس - مشاوره & 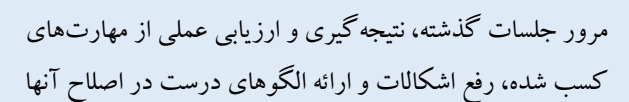 & ارتقاى مديريت كودكك-تحكيم الكوهاى صحيح رضايت & 4 \\
\hline
\end{tabular}




\begin{tabular}{|c|c|c|c|}
\hline تمرين قاطعيت در تشويق و تنبيه- خوددارى از & 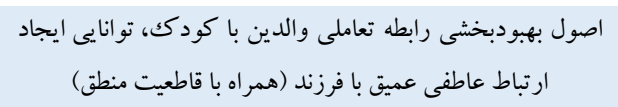 & بهبود رابطه والد-والد و والد-كود دك و قاطعيت & 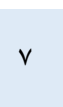 \\
\hline 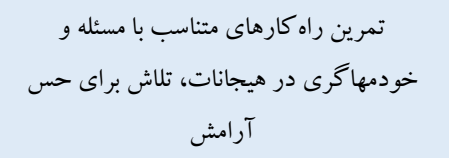 & 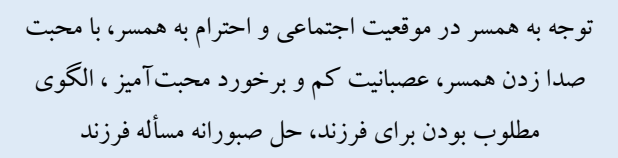 & 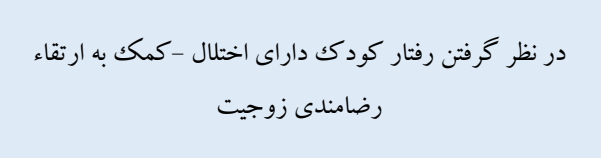 & $\wedge$ \\
\hline 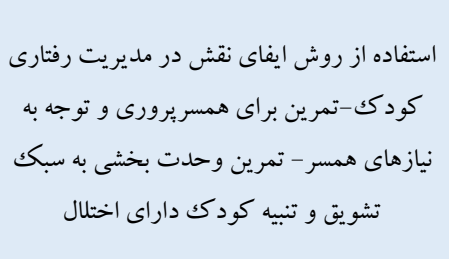 & 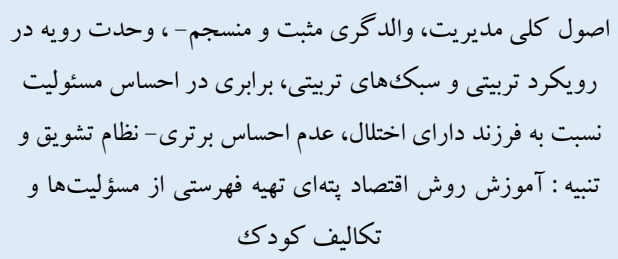 & مناسب -توانميم انظارات با تو انايى هاى كودك - كاربرد تشويق و تنبيه & 9 \\
\hline 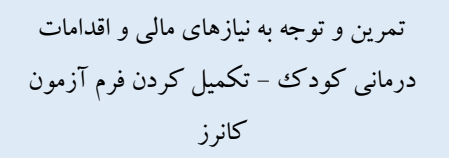 & 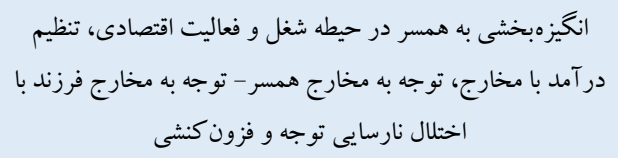 & 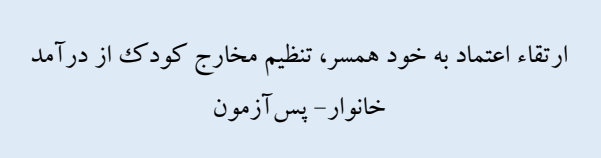 & 1. \\
\hline
\end{tabular}

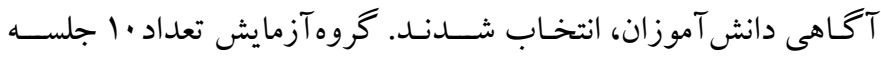
مداخله آموزشسى ــــروانى را به ميزان •ه دقيقه در قالب برنامه مديريت رفتارى خانو ادهمحور به مدت يكك ماه دريافت كردند. در طول اين مدت گروه گواه، آموزشــى را دريـافت نكرده و در نوبت انتظار قرار گرفتند. روش تحليل دادهها در مطالعه حاضـر، تحليل واريانس با تكرار سـنجش

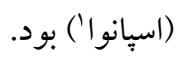

\section{يافته ها}

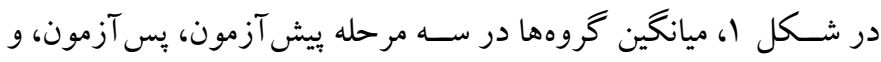
بيخيرى از طريق نمودار نشان داده شده است و در جدول ب شاخصهاى توصـيفى متغيرهاى بزظوهش، شــامل ميانخين و انحر اف اســاندارد براى

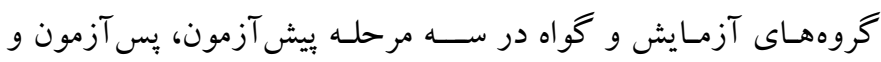

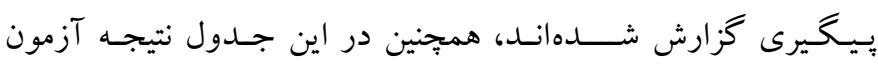
كالمو گروف اســميرنف براى بررسـى نرمـال بودن توزيع دادهها ارائه

شدهاند.
د) روشاجرا: با توجه به نرخ شــيوع ها تا م درصـــ اختلال نارســايى توجـه /فز.ن كنشـى (YF) و ير اكندكى اين كود كان در مدارس، از طريق مشورت با يزٔوهشخران و متخصصان و با نمونه گيرى در دسترس، يكى از از مــدارس برجمعيـت منطقـه f شــهر تهر ان انتخاب شـــــ ابتدا معرفىنامه يثزوهشـ/ با ذكر عنوان بثزوهش از سـوى دانشخاه صادر و بر اساس آن، اداره كل آموزش و برورش شـهـر تهران يس از بررسـى هاى حرفهاى و

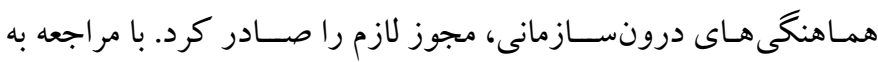
مسدرســه مورد نظر، مـدير مـدرســه هماهنخ هاى للزم جهت حضــور يزوهشــر را ايجاد و از طريق هماهنكى هاى انجام شده و همكارى مؤثر معلمان طى يكك جلســه توجيهى بر اســاس فرم معلم مقياس درجهبندى كانرز (1999)، درباره علائم رفتارى اختلال نارسايى توجه و فزون كنشى، آموزش للازم به معلمان ارائه شد. فرم معلم مقياس درجهبندى كانرز، براى تعداد • rا نفر دختر و يسر در همه يايهها از سوى آموز گاران تكميل شد. يس از بررسـى و تحليل برسـشــامهها، افراد نمونه ضـمن رعايت اصـول

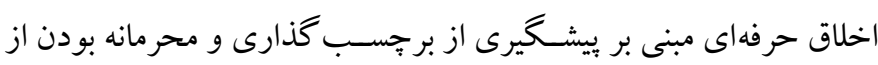




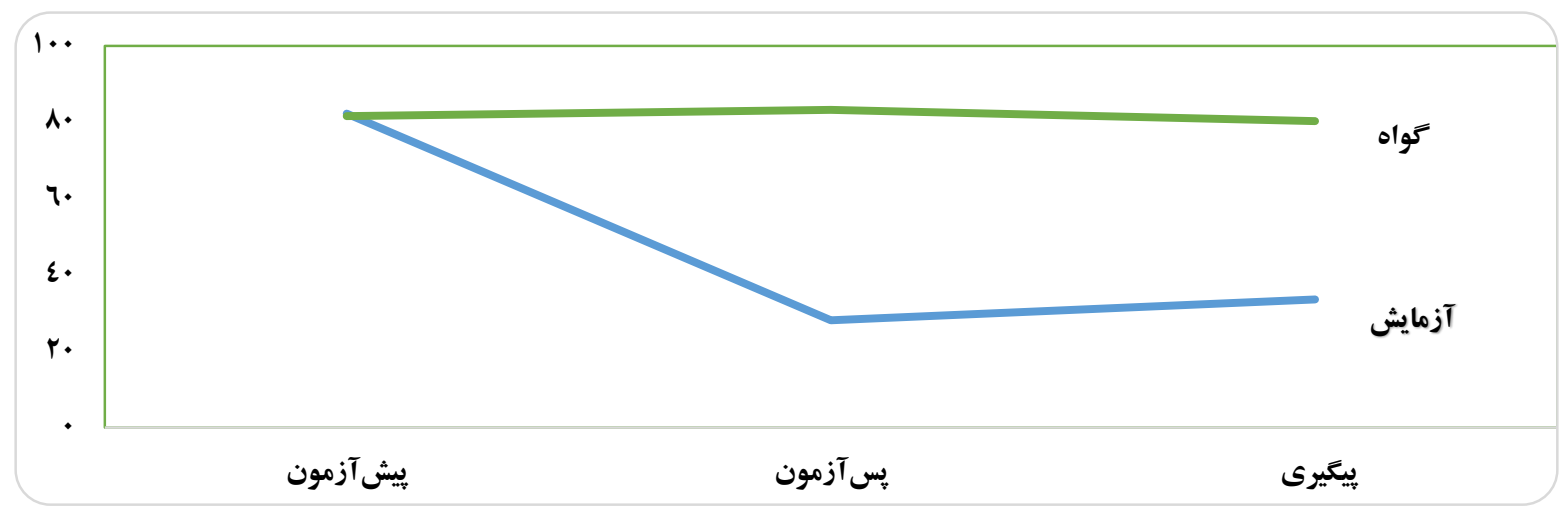

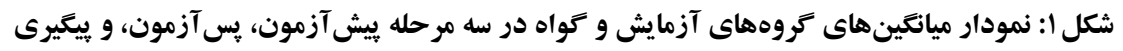

جدول ז: شاخصهاى توصيفى متغير يزوهش براى كروه آزمايش و كواه در سه مرحله ييش آزمون، يس آزمون، و بييكيرى

\begin{tabular}{|c|c|c|c|c|c|c|}
\hline سطح معنادارى & TK-S ZKاره & انحر اف استاندارد & ميانكين & كروه & مرحله & متغير \\
\hline .1 .9 & $\cdot / r$. & $I V / F T$ & $\Lambda Y / Y \Lambda$ & آزمايش & \multirow{2}{*}{ بيش آزمون } & \multirow{4}{*}{ سطح اختلال نارسايى توجه و فزون كنشى } \\
\hline$\cdot / r$. & $\cdot / \Lambda$ & $r Y / 94$ & N1/9Y & كو اه & & \\
\hline$\cdot / 11$ & $\cdot / r$ & $9 / \Delta 1$ & $\Lambda \Gamma / r \Lambda$ & كو اه & 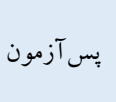 & \\
\hline$\cdot / l F$ &.$/ 19$ & $10 / 94$ & $M T / \Delta Q$ & آزمايش & يِيرى & \\
\hline
\end{tabular}

براى بررسـى فرضـيه يثزوهش از تحليل واريانس با تكرار ســنش

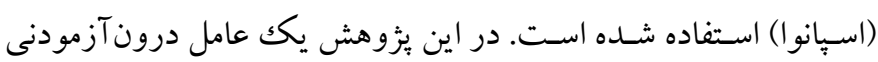

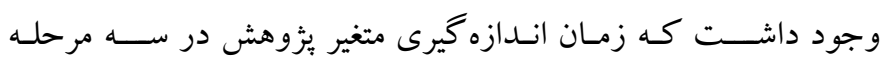
بيش آزمون، يس آزمون، و يِيخيرى بود و يـك عـامل بين آزمودنى وجود داشـت كه آن عضسويت كروه بود؛؛ لذا طرح مورد اسـتفاده طرح درونبين آزمودنى' اسـت. در اين بخش نتايج آزمون تحليل واريانس با تكرار سـنجش براى كرووهها ار ائه مى شـود، سـيس در بخش بعدى، مقايسه هاى زوجى گروهها ارائه مىشـود. در جدول ب نتايج آزمون مو جلى به منظور بررسى كرويت متغير يزٔوهش كزارش شده است.
با توجه به شكل ا، در متغير ميزان اختلال نارسايى توجه و فزون كنشى

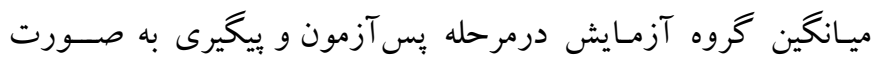
معنادارى به دليل كاهش ميزان اختلال، كمتر از مرحله بيش آزمون است امـا در كروه گواه بـه دليـل عـدم كـاهش اختلـال، در ميانگين مرحله يس آزمون و بيخيرى تفـاوت معنادارى با مرحله بيش آزمون، مشــاهده نشــــهمجينين بـا توجـه بـه جـدول Y، آمـاره Z آزمون كـالمو اسـميرنف براى متغير ياد شــه در هيتج كدام از گروهها معنادار نيســ؛ بنابر اين توزيع تمامى متغيرها نرمال اسـت. همجينين يافتهاى جدول نشان مىدهـد كـه ميـانخين كروه آزمـايش از بيش آزمون تـا يس آزمون و از

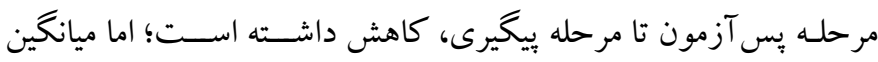
كروه گُ اه در طى اين مر احل تغييرات محسوسى نداشته است.

جدول ז: نتايج آزمون موجلى جهت بررسى كرويت

\begin{tabular}{|c|c|c|c|c|c|c|}
\hline إيسيلون هاين فلت & إيسيلون كرين هاوس & سطح معنادارى & درجه آزادى & مجذور خى & W موجلى W & متغير \\
\hline.$/ 94 Y$ & - /AFG & $\% r$ & r & $\mid r / Y q$ & $\cdot / \mathrm{AIV}$ & سطح اختلال نارسايى توجه و فزون كنشى \\
\hline
\end{tabular}

1 - Within- Between Subject Analyze of Variance 
فلت براى تصـحيح درجه آزادى استفاده شـد. با در نظر گرفتن تصحيح

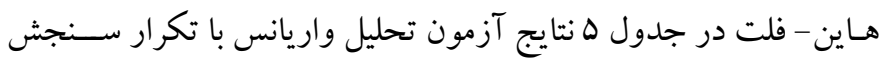

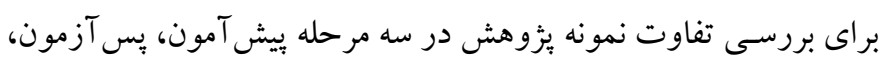

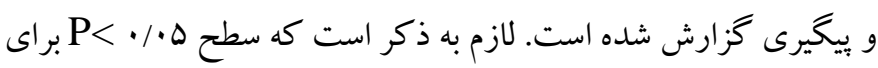

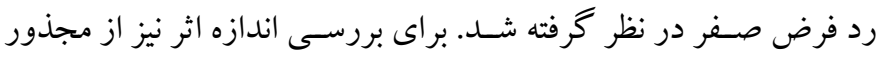

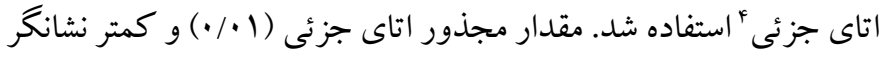

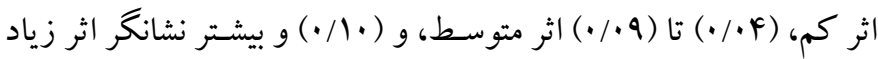

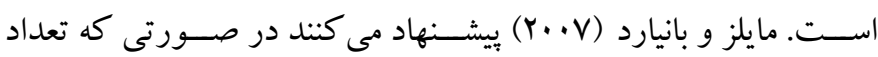

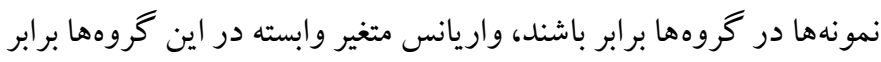

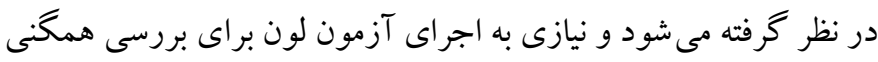

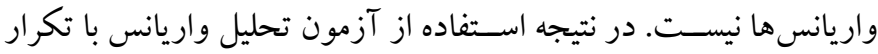
سـنش (اسِيانو) به منظور ارزيابى اثربخشى متغير مستقل بر متغير وابسته بلامانع است.
نتايج جدول ب نشــان مىدهد كه آماره W مو جلى براى متغير ميزان

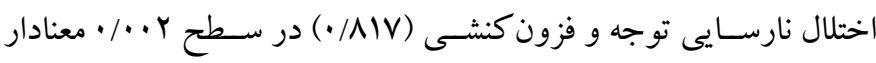

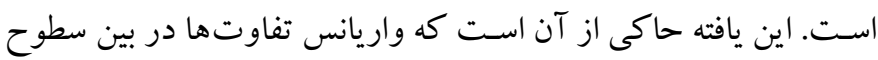
متغير وابسـته به صــورت معنادارى متفاوت اســت؛ بنابر اين بيشفرض كرويت رعايت نمىشــود. تخطى از ييشفرض كرويت باعث مىشـود آماره F تحليل واريانس دقيق نباشد. براى رفع اين مشكل و افزايش دقت

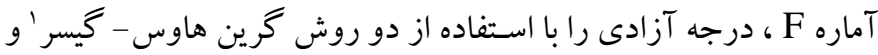

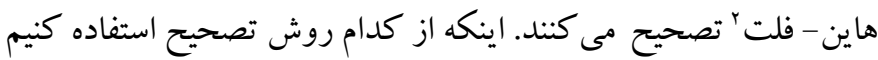

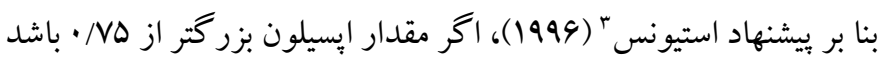

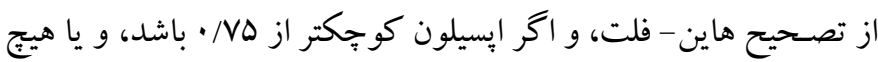

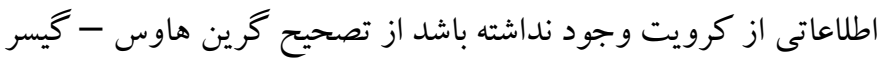

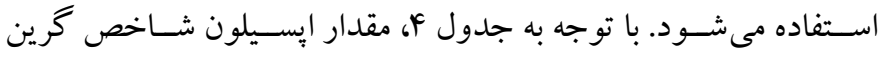
هاوس-گيسـر بيشتر از له/ · بزر گتر اسـت و بنابر اين از إيسيلون هاين -

جدول ع: نتايج آزمون تحليل واريانس براى بررسى تفاوت نمونه يزوهش در سه مرحله ييش آزمون، يس آزمون، و ييكيرى

\begin{tabular}{|c|c|c|c|c|c|c|c|}
\hline مجذور اتا & سطح معنادارى & foار & ميانكين مجموع مجذورات & درجه آزادى & مجموع مجذورات & منابع & متغير \\
\hline$\cdot / 01$ & $\cdot / \cdot 1$ & $19 / Y \Lambda$ & $r \mid \Delta / M$ & 1 & rID/M & كروهol & سطح اختلال \\
\hline$\cdot / \Delta r$ & $\cdot / \cdot 1$ & $\Delta q / \Gamma q$ & $I I V / r V$ & $1 / r V$ & $\mid Y F / M^{\prime}$ & مراحل & نا رسايى توجه \\
\hline$\cdot / 4 \wedge$ & $\cdot / \cdots 1$ & $1 \pi / 1 V$ & $\Delta \Delta / \cdot \Delta$ & $r / \cdot r$ & $M N / \cdot 1$ & تعامل مراحل با & و فزون كنشى \\
\hline
\end{tabular}

تمامى متغيرها بيشـتر از • / • اسـت كه نشـان مىدهد تفاوت بين كروهها بزرگك و قابل توجه است. به منظور بررسسى تفاوت گروه تحت آموزش برنامه مديريت رفتارى خـانوادهمحور (آزمـايش) بـا گروه گواه در متغير زئوهش در جـدول 4 نتايج مقايسـه ميانخين گروهها در سـه مرحله يِيش آزمون، يس آزمون، و بيخيرى گز ارش شده است.
همان طور كه در جدول F نشـان داده شـده است، ميزان F اثر تعامل

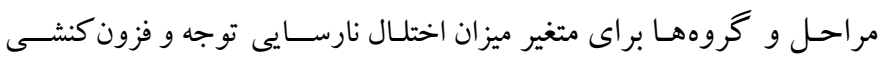
(I اسـت كه در سـح IVIV) كـه گروههـاى آزمـايش و كواه از لحـاظ متغير يزوهش (ميزان اختلـال نارســايى توجه و فزون كنشـى) در ســهـ مرحله بيش آزمون، يس آزمون، و

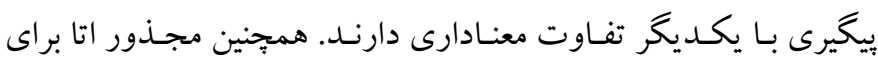

جدول 0: نتايج مقايسه ميانكين كروهها در سه مرحله بيش آزمون، يس آزمون، و ييتيرى در متغير يزوهش

\begin{tabular}{|c|c|c|c|c|c|c|}
\hline سطح معنادارى & خطاى استاندارد بر آورد & تفاوت ميانكين & ميانكين كنترل & ميانكين آزمايش & مرحله & متغير \\
\hline$\cdot / \cdots$ & $\cdot|\Delta|$ & -.199 & $11 / 9 r$ & $\Lambda Y / Y \Lambda$ & ي يش آزمون & سطح اختلال \\
\hline$\cdot / \cdots$ & $1 / \cdot r$ & $\Delta \Delta / 1$ & $\Lambda \mu / r \Lambda$ & YN/1Q & يس آزمون & نارسايى توجه \\
\hline$\cdot / \cdots$ &.$/ 90$ & KG/VQ & $\Lambda \cdot / \mu_{1}$ & $r r / \Delta Q$ & ي ي يخيرى & و فزون كنشى \\
\hline
\end{tabular}

3. Stevens

4. Partial eta squared
1. Greenhouse-Geisser

2. Huynh-Feldt 
رفتـارى مر تبط بـا اختلال نـارسـايى توجه و فزون كنشسى مانند بى تو جهى،

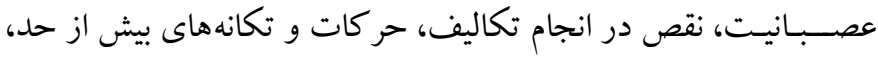

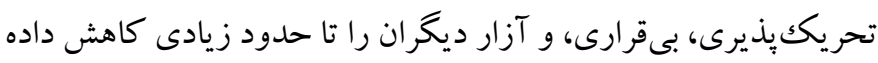

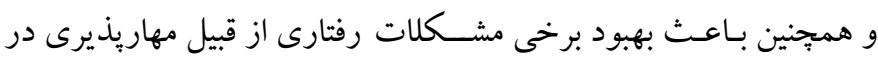

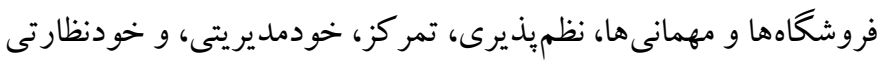

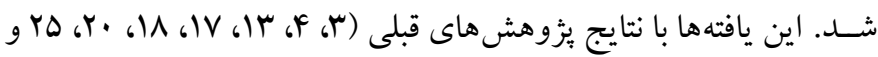
(19) همسو است. (19)

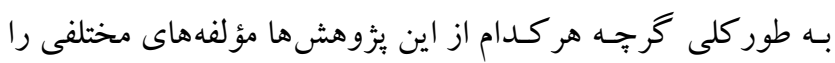

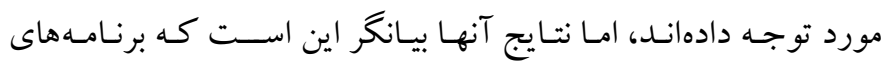
آموزشى - مداخلهاى خانو ادهمحور مى تواند منجر به كاهش ميزان اختلال

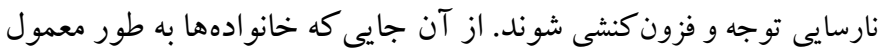

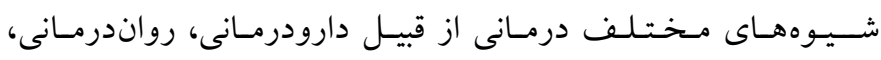

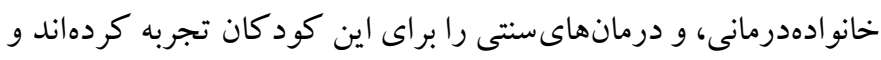

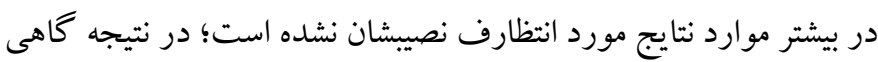

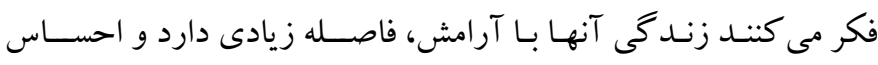

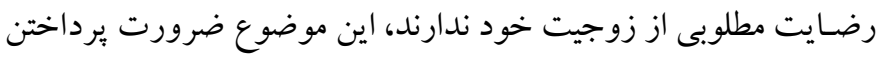

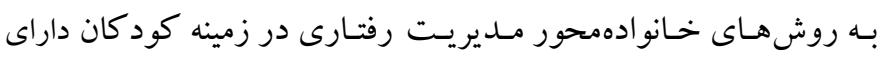

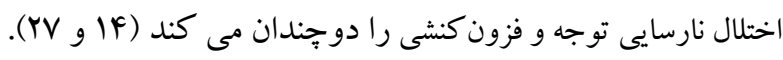
رفتارهاى ناشى ازاختلال نارسايى توجه و فزون كنشى اغلب منجر به آسـيب در روابط خانواده و والد - كودكك و افزايش تنش در ميان

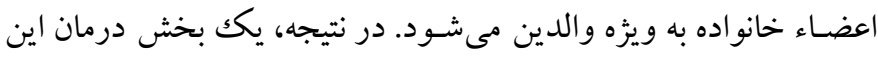

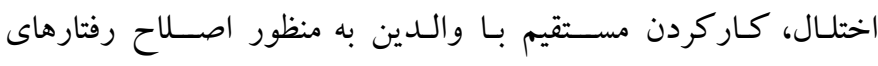

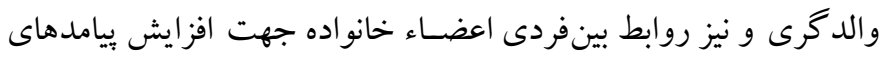

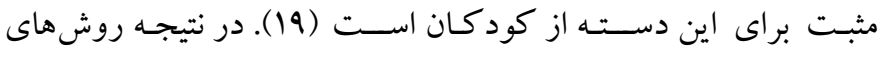

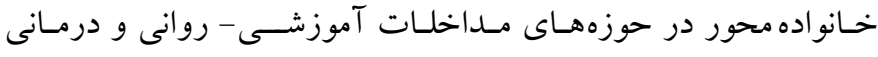
مى توانتـــ بـه جاى فرد، خانو اده را كانون توجه قرار داده و به دنبال تغيير

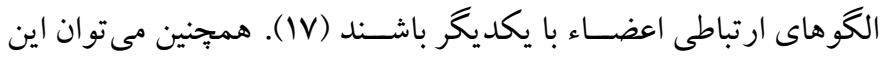

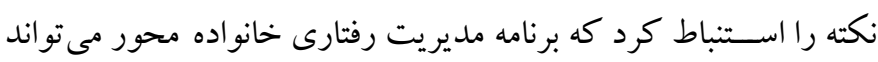

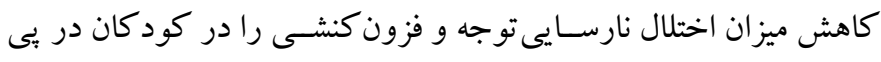

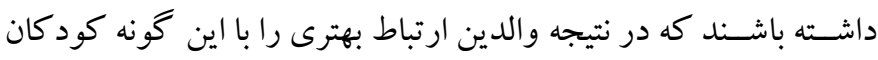

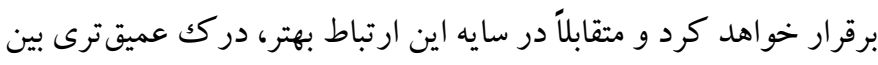

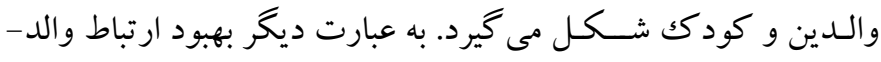

با توجه به جدول ه، در متغير ميزان اختلال نارسايى توجه و فزون كنشى

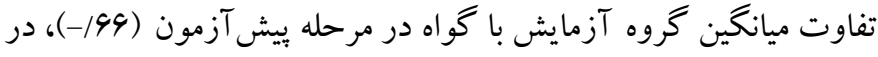

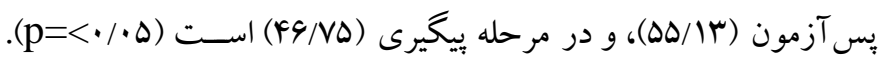

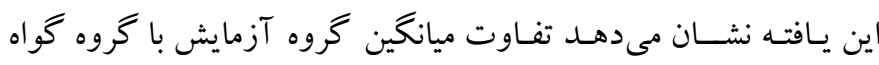

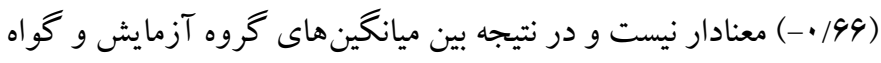

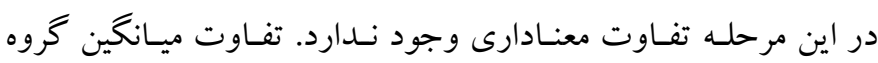

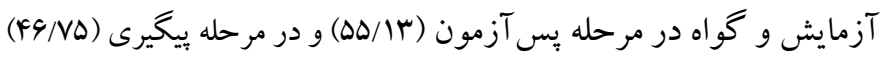

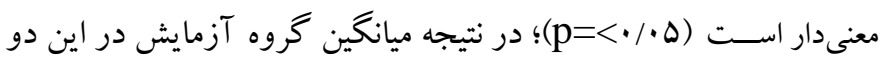

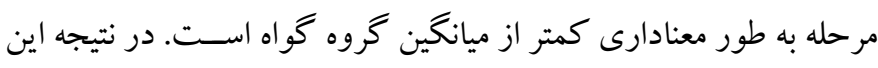

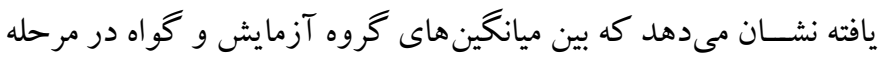

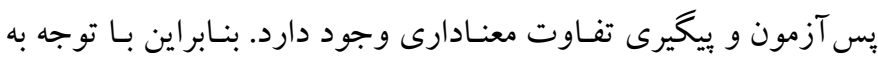

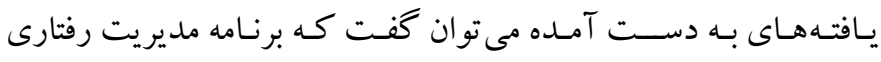

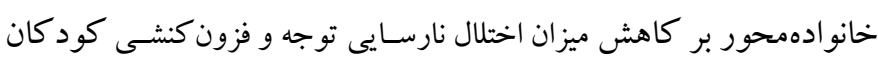
دبستانى، اثربخشى مثبت و معنادارى داشته است.

\section{بحث و نتيجه Fيرى}

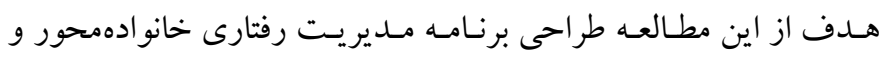

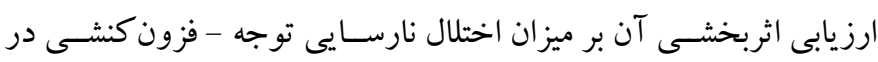

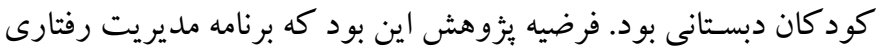

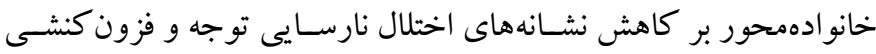

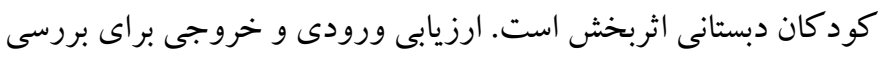

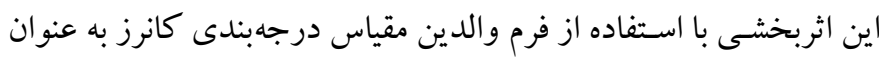

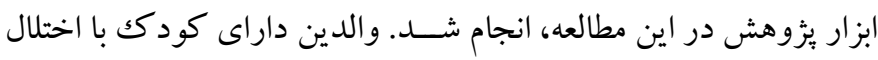

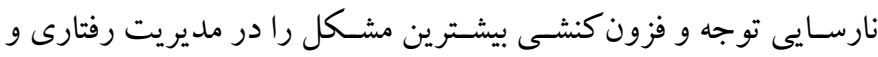

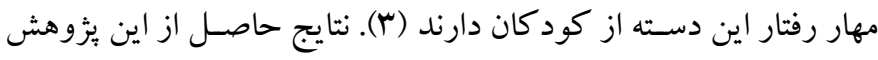

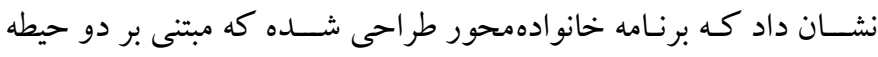

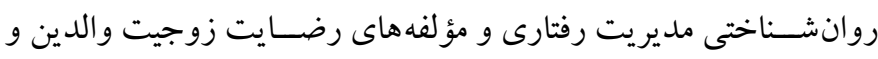

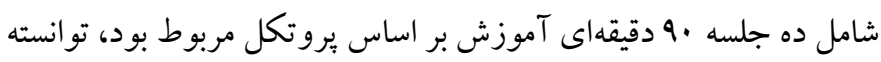

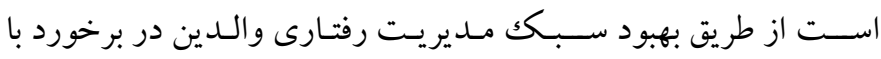
كود كانشـان و بهبود رضـايت زوجيت آنان، بر كاهش ميزان اختلال اين رودي دسته از كود كان، اثربخشى مثبت و مستقيمى داشته است. يافته هاى اين

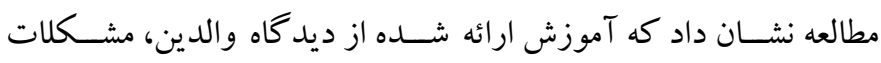


براى گروههـاى مختلف بـا فرهنك هـاى متفاوت و اقليمهاى گوناگون،

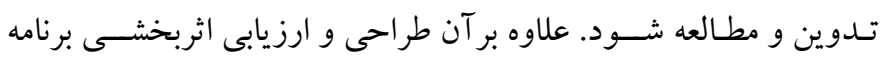

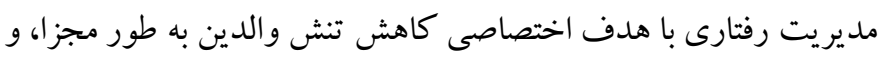

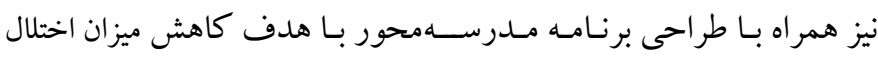

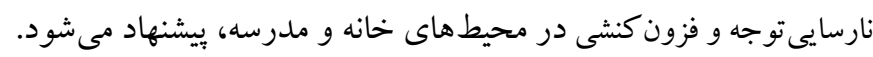
تشـكر و قدردانى: اين يُوهش بركرفته از رسـاله دكتراى آقاى على اكبر

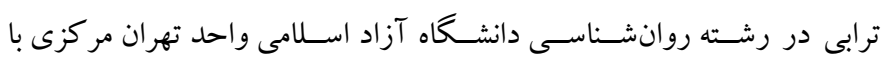

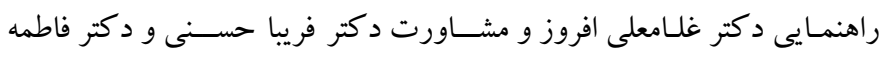

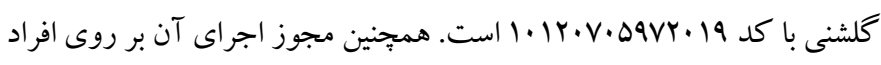

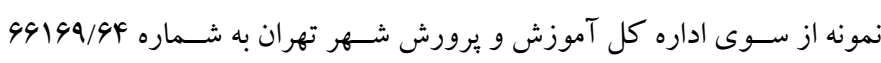

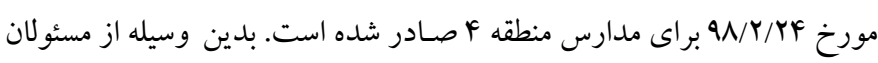

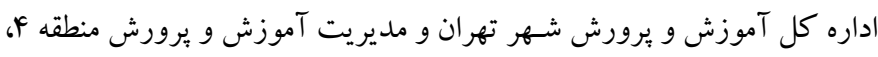

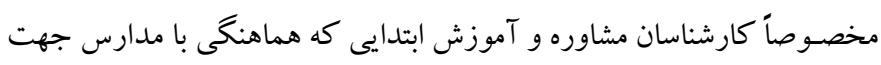

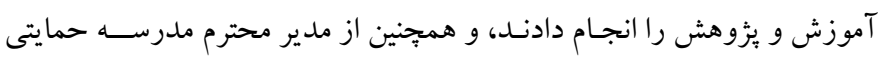

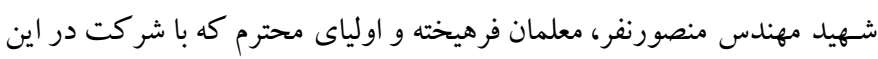
يُزوهش به ما كمك كردند، كمال تشكر و قدردانى مىشود. تضـاد منافع: اين يُزوهش براى نويسـند گان هيج گونه تضـاد منافع به دنبال

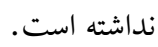

والد، باعث بهبود رابطه والد- كود كك و در نهايت كود كك- والد خواهد

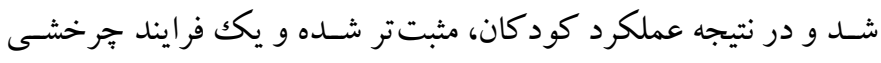
سالمترى را رقم مىزند. بثزوهش حاضـر با محدوديتهايى روبرو بوده اسـت كه بيان آنها در

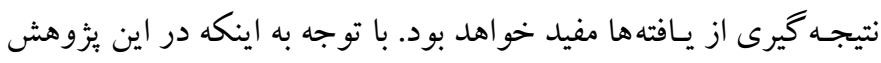

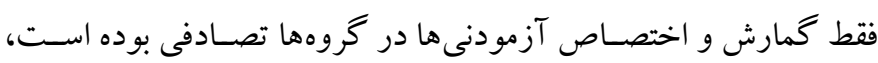
باز گشت آمارى و رخدادهاى همزمان با انجام يزٔوهش ممكن است است اعتبار

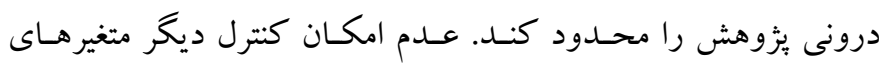

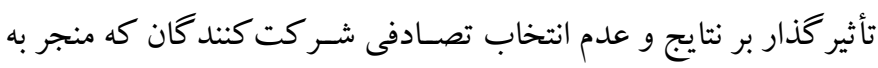

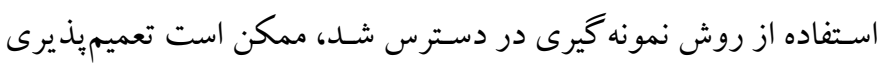

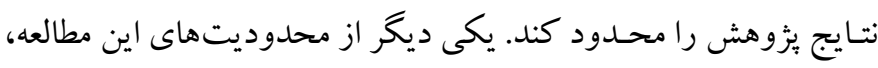

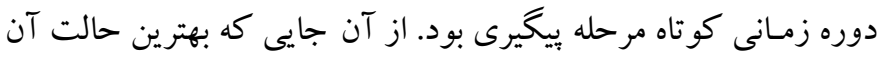

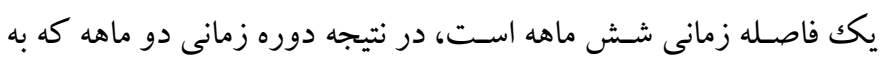

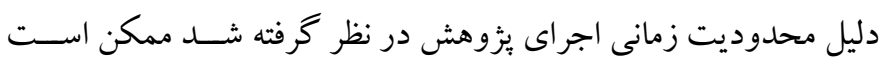

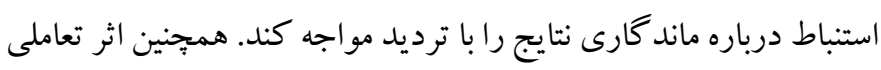

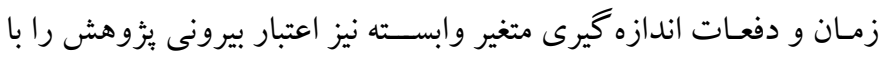

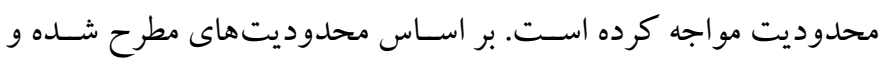

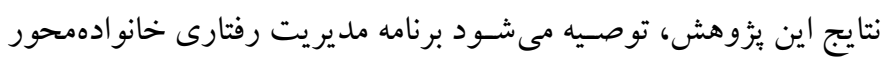




\section{References}

1. Yasumura A, Omori M, Fukuda A, Takahashi J, Yasumura Y, Nakagawa E, et al. Age-related differences in frontal lobe function in children with ADHD. Brain Dev. 2019; 41(7): 577-586. [Link]

2. Fischer BA. A review of American psychiatry through its diagnoses: The history and development of the diagnostic and statistical manual of mental disorders. J Nerv Ment Dis. 2012; 200(12): 1022-1030. [Link]

3. Weyandt L. Book review: Barkley, R. A. (2006). Attention-deficit hyperactivity disorder: A handbook for diagnosis and treatment (3rd ed.). New York: Guilford. J Atten Disord. 2007; 11(2): 179-180. [Link]

4- Naseh A. The effect of mindfulness-based group intervention on self-esteem and social problems in students with symptoms of attention deficit / hyperactivity disorder. Quarterly Journal of Child Mental Health. 2019; 6(3): 256-268. [Persian]. [Link]

5. Zhao X, Page TF, Altszuler AR, Pelham WE, Kipp H, Gnagy EM, et al. Family burden of raising a child with ADHD. J Abnorm Child Psychol. 2019; 47(8): 13271338. [Link]

6. American Psychiatric Association. Diagnostic and statistical manual of mental disorders (DSM-5®). American Psychiatric Pub; 2013, pp: 59-66. [Link]

7. Farshad MR, Najarpourian S, Shanbedi F. The effectiveness of the positive parenting education based on sanders' approach on happiness and parent-child conflict of students. Quarterly Journal of Child Mental Health. 2018; 5(1): 59-67. [Persian]. [Link]

8. Bell CC. DSM-IV: Diagnostic and statistical manual of mental disorders. JAMA. 1994; 272(10): 828-829. [Link]

9. Davison GC, Blankstein KR, Flett GL, Neale JM. Abnormal psychology. 5 edition. Wiley; 2013, pp: e221-223.[Link]

10. Davison GC, Neale JM. Abnormal psychology. 6th ed. New York: John Wiley; 1994, pp: e316-318. [Link]

11. Bussing R, Mason DM, Bell L, Porter P, Garvan C. Adolescent outcomes of childhood attentiondeficit/hyperactivity disorder in a diverse community sample. J Am Acad Child Adolesc Psychiatry. 2010; 49(6): 595-605. [Link]

12. Guze SB. Diagnostic and statistical manual of mental disorders, 4th ed. (DSM-IV). Am J Psychiatry. 1995; 152(8): 1228-1228. [Link]
13. Williford AP, Shelton TL. Behavior management for preschool-aged children. Child Adolesc Psychiatr Clin N Am. 2014; 23(4): 717-730. [Link]

14. Donsky A. Taking charge of ADHD: The complete authoritative guide for parents. Revised edition. Can Child Adolesc Psychiatr Rev. 2003; 12(4): 124. [Link]

15. Baucom DH, Epstein N, Sayers S, Sher TG. The role of cognitions in marital relationships: definitional, methodological, and conceptual issues. J Consult Clin Psychol. 1989; 57(1): 31-38. [Link]

16. Zainali N, Afrooz G, Gholamali Lavasani M, Ghasemzadeh S. The effectiveness of family-based psychology program on marital satisfaction and their children's affiliation to computer games. Contemporary Psychology, Biannual Journal of the Iranian Psychological Association. 2018; 12(2): 100113. [Persian]. [Link]

17. Danforth JS. A flow chart of behavior management strategies for families of children with co-occurring attention-deficit hyperactivity disorder and conduct problem behavior. Behav Anal Pract. 2016; 9(1): 6476. [Link]

18. Bayrami M, Abdollahi E, Hashemi nosrat abad T. The effectiveness of parent management training on improvement of attention deficit hyperactivity disorder in children with epilepsy: Single subject study. Razi Journal of Medical Sciences. 2017; 24(157): 90-98. [Persian]. [Link]

19. Zubrick SR, Ward KA, Silburn SR, Lawrence D, Williams AA, Blair E, et al. Prevention of child behavior problems through universal implementation of a group behavioral family intervention. Prev Sci. 2005; 6(4): 287-304. [Link]

20. Ghasemi N, Nori L, Abdi Zarrin S. The effect of parent management training (PMT) on the reduction of behavioral symptoms in children with attention deficit hyperactivity disorder (ADHD). Quarterly Journal of Child Mental Health. 2019; 6(2): 1-12. [Persian]. [Link]

21. Charmforoush Jalali L, Hasanzadeh S, Davaee M, Afrooz G. Development and assessment of effects of de-stress training program on stress of mothers with mentally disabled children. Iranian Rehabilitation Journal. 2016; 14(4): 223-228. [Link]

22. Haji Seyed Javadi T, Borjali M, Borjali A. Effectiveness of Barkley's behavioral parent training in reducing symptoms of children with attention deficit hyperactivity disorder. The Journal of Qazvin University of Medical Sciences. 2014; 17(6): 47-52. [Persian]. [Link] 
23. Ravaei F, Afrooz G, Hosseinian S, KhodayariFard M, Farzad V. Effectiveness of family- based Islamic Iranian oriented psychological program in marital satisfaction. Journal of Family Psychology. 2016; 3(1): 17-30. [Persian]. [Link]

24. Shahim S, Mehrangiz L, Yousefi F. Prevalence of attention deficit hyperactivity disorder in a group of elementary school children. Iran J Pediatr. 2007; 17(2): 211-216. [Persian]. [Link]

25. Shahim S, Yousefi F, Shahaeian A. Standardization and psychometric characteristics of the Conners' teacher rating scale. Journal of Psychology and Education. 2007; 14(1-2): 1-26. [Persian]. [Link]
26. Alizadeh $\mathrm{H}$, Andries C. Interaction of parenting styles and attention deficit hyperactivity disorder in Iranian parents. Child Fam Behav Ther. 2002; 24(3): 37-52. [Link]

27. Afrooz, Gh. A. (2017). Review on practicality reliability, validity and normalization of couple's satisfaction scale among married women teachers in Tehran city. Journal of applied psychological research. Volume 7, Issue 4. pp: 163-179. [Persian].[Link] 